\title{
EFEKTIFITAS AKUPRESUR TITIK HEGU-SANGCIU DAN KOMPRES AIR HANGAT PADA LEHER TERHADAP NYERI POST INTUBASI DI RSUD PROF. DR. MARGONO SOEKARJO
}

\author{
Arif Mubarok* \\ Asep Hidayat** \\ Suryo Febriyanto*** \\ *) Unit Perawatan Intensif RSUD Prof. Dr. Margono Soekarjo, Jl. Dr. Gumbreg No.1, \\ Kebontebu, Berkoh, Purwokerto Sel., Kabupaten Banyumas, Jawa Tengah 53146, telp: \\ 081319837933 , email : mubahrokarief7@gmail.com
}

Corresponding Author: Arif Mubarok

\begin{abstract}
Abstrak
Intubasi merupakan prosedur yang sering dilakukan di ruang Intensive Care Unit (ICU). Adanya intubasi juga mengakibatkan nyeri, prevalensi nyeri post intubasi terjadi sebesar 90\% (Suhera Beevi, 2010). Beberapa penelitian menunjukkan stigma yang kurang baik pada penggunaan terapi farmakologi dalam mengatasi nyeri (Brown, 2014). Akupresur salah satu teknik pengobatan tradisional Cina yang dapat digunakan untuk menurunkan nyeri. Kompres hangat juga merupakan salah satu teknik dalam menurunkan intesitas nyeri. Tujuan penelitian ini adalah untuk mengetahui efektifitas akupresur titik hegu-sangciu dan kompres air hangat pada leher, terhadap penurunan nyeri pasien post intubasi. Metode penelitian ini adalah quasy experiment dengan desain non equivalen pre and post control. Pengambilan sampel menggunakan consecutive sampling. Sejumlah 20 responden yang telah memenuhi kriteria inklusi untuk masing-masing kelompok perlakuan. Instrumen yang digunakan adalah skala Non Verbal Pain Scale (NVPS). Pada analisis univariat data disajikan dalam bentuk distribusi frekuensi. Pada Analisis bivariat digunakan uji T berpasangan dengan nilai kemaknaan $\mathrm{p}<0,05$. Hasil penelitian menunjukkan ada pengaruh intensitas nyeri yang bermakna sebelum dan sesudah dilakukan kompres hangat $p=0.00(p<0.05)$. Sebaliknya, didapatkan tidak ada pengaruh intensitas nyeri yang bermakna antara pengambilan data sebelum dan sesudah pada kelompok akupresur $p=0.074(p>0.05)$. Oleh karena itu, kompres hangat lebih disarankan untuk digunakan dalam mengatasi nyeri pasien post intubasi.
\end{abstract}

Kata kunci: Akupresur, Kompres Hangat, Nyeri 
Jurnal IImu Keperawatan Medial Bedah 1 (2), Desember 2018, 1-57

ISSN 2338-2058 (print), ISSN 2621-2986 (online)

\section{PENDAHULUAN}

Intubasi merupakan prosedur memasukan pipa endotrakea (ETT) ke dalam rongga jalan nafas atas atau trakea baik melalui rongga mulut maupun hidung (Wardani, 2011). Intubasi umumnya di gunakan untuk memproteksi jalan nafas dan memungkinkan di lakukan kontrol terhadap ventilasi dan oksigenasi (Morgan, 2010). Intubasi merupakan prosedur yang paling sering dilakukan di ruang Intensive Care Unit (ICU).

Namun adanya intubasi juga dapat mengakibatkan efek yang tidak diharapkan, yaitu: iritasi mukosa trakea yang mengakibatkan sensasi nyeri pada pasien post intubasi (Mort, 2007). Nyeri tenggorokan ini mempunyai prevalensi yang tinggi hampir semua pasien mengalami nyeri setelah diintubasi. Mort (2007) mengatakan 90\% prevalensi nyeri pasca intubasi.

Nyeri pada pasien post intubasi dapat terjadi karena proses inflamasi pada area trakea utamanya bagian posterior pita suara, krikoid, dan anterior dari trakhea. International Association for Study of Pain (IASP) mendefinisikan nyeri sebagai pengalaman perasaan yang tidak menyenangkan akibat terjadinya kerusakan aktual maupun potensial.

Beberapa penelitian menunjukan stigma yang kurang baik pada penggunaan obat-obat penurun rasa nyeri (Sally, 2013). Ketakutan akan terjadinya adiksi, toleransi, depresi pernapasan, dan ketergantungan menyebabkan klien menghentikan penggunaan analgesia. Tramadol yang merupakan opioid sintetis memiliki efek samping mual, muntah, konstipasi, dan konfusi pada lansia. Obat anti inflamasi non-steroid menyebabkan dispepsia, perdarahan lambung, kerusakan saluran cerna, dan nefritis ginjal akut (Kneale \& Davis, 2011).

Akupresur merupakan salah satu teknik pengobatan tradisional Cina yang dapat digunakan untuk menurunkan nyeri, mengobati penyakit dan cidera. Akupresur dilakukan dengan memberikan tekanan fisik pada beberapa titik pada permukaaan tubuh yang merupakan tempat sirkulasi energi dan keseimbangan pada kasus gejala nyeri. Teknik akupresur ini tidak invasif, aman, dan efektif. Akupresur terbukti dapat mengurangi nyeri punggung, kepala, osteoarthritis, otot, leher, nyeri pre-operasi dan postoperasi, mual muntah, dan masalah tidur (Sukanta, 2008).

Kompres hangat juga merupakan salah satu teknik dalam menurunkan intesitas nyeri, kompres hangat dapat meningkatkan vaskularisasi dan juga menghambat rangsang nyeri pada 
spina chordae, beberapa jurnal penelitian kompres hangat dapat menurunkan skala nyeri pada pasien gouth, nyeri haid, dan rematik.

Aini (2010) dalam penelitianya menjelaskan bahwa ada pengaruh kompres air hangat dalam mengurangi nyeri pada pasien gout dan artritis di rumah sakit manado. Air hangat suhu 40$50{ }^{0} \mathrm{C}$ memiliki dampak fisiologis bagi tubuh, pelunakan jaringan fibrosa dapat meningkatkan oksigenasi jaringan melalui vasodilatasi pembuluh darah, otot menjadi lebih rileks, dan nyeri menjadi berkurang (Mahmud, 2007). Hal ini dapat dijadikan landasan bahwa kompres air hangat dapat mengatasi nyeri post intubasi. Kompres air hangat ini adalah pemberian kompres pada area leher dengan suhu $40-50^{\circ} \mathrm{C}$ selama 20-30 menit. Pada suhu tersebut toleransi kulit dapat di capai dengan baik tanpa menyebabkan luka bakar. Sedangkan Aghda N.S (2012) dalam penelitianya melakukan akupresur pada titik BL32 dan GB21 untuk mengurangi nyeri persalinan pada kala 1, dengan menggunakan skala VAS mempunyai hasil penelitian yang signifikan dalam menurunkan skala nyeri kala 1.

Pengambilan data awal di Ruang ICU RSUD Prof. dr. Margono Soekarjo tahun 2017 ditemukan sebanyak 324 pasien yang terpasang ETT, dan pada Mei-Juli 2017 sebanyak 168 pasien yang terpasang ETT dengan 108 pasien sadar dengan GCS (E4 M6 Vet) dan dapat dikaji skala nyeri, pengambilan data pasien menggunakan non verbal scale pain dan seratus pasien mengatakan nyeri, 38 pasien mengatakan nyeri skala berat $(35,1 \%), 64$ pasien skala nyeri sedang $(59,2 \%)$, dan 6 pasien mengatakan nyeri skala ringan $(5,7 \%)$. Sedangkan 60 pasien yang tingkat kesadaran dengan GCS di bawah 14 tidak dilakukan pengumpulan data.

Berdasarkan data tersebut peneliti tertarik untuk melakukan penelitian tentang Efektifitas akupresur pada titik hegu-sangciu dan kompres air hangat pada leher terhadap penurunan nyeri pada pasien post intubasi di ruang ICU RSUD Prof. dr. Margono Soekarjo. 


\section{METODE PENELITIAN}

Penelitian ini bersifat quasy experiment dengan desain non equivalen pre and post control. Penelitian dilaksanakan di ruang ICU RSUD Prof. Margono Soekarjo pada periode Januari-Maret 2018.

\section{Skema Penelitian}

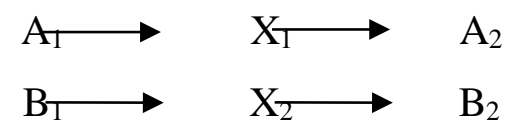

\section{Keterangan :}

$\mathrm{X}_{1}=$ Perlakuan 1 (kompres hangat)

$\mathrm{X}_{2}=$ Perlakuan 2 (Akupresur)

$\mathrm{A}_{1}=$ Pre-test kelompok kompres hangat

$\mathrm{A}_{2}=$ Post-test kelompok di kompres hangat

$\mathrm{B}_{1}=$ Pre-test kelompok akupresur

$\mathrm{B}_{2}=$ Post-test kelompok akupresur

Pengambilan sampel menggunakan consecutive sampling. Sampel berjumlah 20 responden yang telah memenuhi kriteria inklusi untuk masing-masing kelompok perlakuan. Kriteria inklusi pada penelitian ini adalah Pasien terintubasi atas indikasi operasi maupun gagal nafas, Pasien GCS=15, Usia 18-50 tahun, bersedia menjadi responden penelitian (informed consent). Sedangkan kriteria eksklusinya adalah pasien GCS $<10$.

Instrumen yang digunakan dalam penelitian ini adalah skala Non Verbal Pain Scale (NVPS) untuk mengukur skala nyeri responden yang dilakukan kompres hangat dan akupresur. Pengambilan data dilakukan dengan pengamatan terhadap responden langsung sebelum dan setelah dilakukan perlakuan. 
Tabel 1

Non Verbal Pain scale (NVPS)

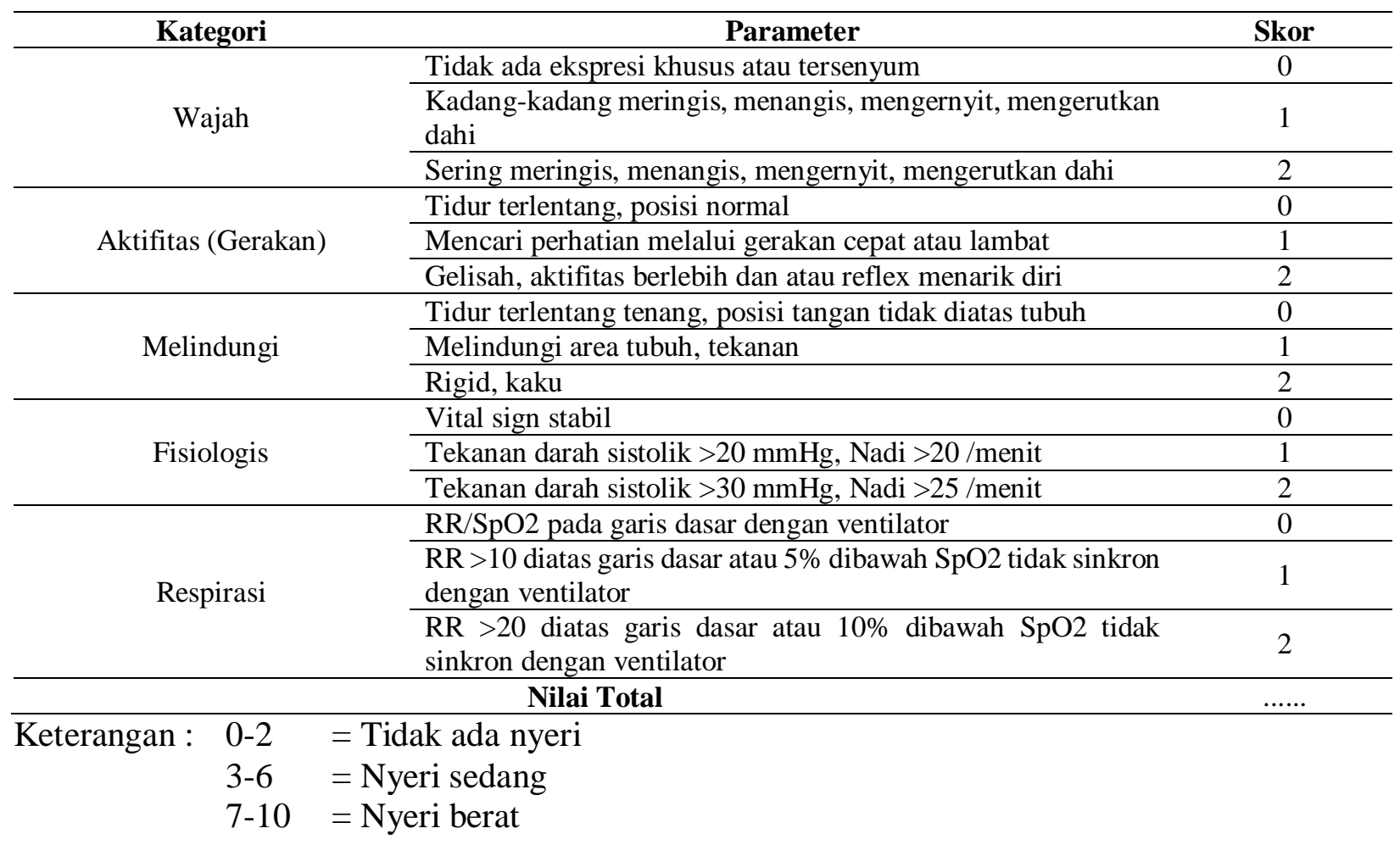

Analisis data penelitian dilakukan dengan program komputer SPSS. Pada Analisis univariat data disajikan dalam bentuk distribusi frekuensi. Kemudian dilakukan Analisis bivariat dilakukan untuk mengetahui pengaruh sebelum dan sesudah intervensi menggunakan uji $\mathrm{T}$ berpasangan dengan nilai $p<0,05$.

\section{HASIL DAN PEMBAHASAN}

\section{Hasil Penelitian}

\section{Karateristik Responden}

Tabel 2

Mubarok, A., Hidayat, A., \& Febriyanto, S. / Efektivitas Akupressure Titik Hegu-Sangciu...Hal 51 dari 57 
Distribusi Frekuensi Responden Penelitian berdasarkan Jenis Kelamin, Jenis Operasi, dan Jenis Analgetik pada Kelompok Intervensi Kompres Hangat dan Kelompok Intervensi Akupresur di Ruang ICU Rumah Sakit Margono Soekarjo pada Januari-Maret 2018 (n=40)

\begin{tabular}{|c|c|c|c|}
\hline Karakteristik Responden & $\begin{array}{c}\text { Kompres Hangat } \\
\text { f }(\%)\end{array}$ & $\begin{array}{c}\text { Akupresur } \\
\text { f }(\%)\end{array}$ & Total \\
\hline $\begin{array}{c}\text { Jenis Kelamin: } \\
\text { • } \quad \text { Laki-laki } \\
\text { • }\end{array}$ & $\begin{array}{r}12(60 \%) \\
8(40 \%)\end{array}$ & $\begin{array}{r}9(45 \%) \\
11(55 \%)\end{array}$ & $\begin{array}{l}21(52,5 \%) \\
19(47,5 \%)\end{array}$ \\
\hline 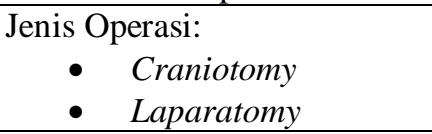 & $\begin{array}{r}12(60 \%) \\
8(40 \%) \\
\end{array}$ & $\begin{array}{c}9(45 \%) \\
11(55 \%)\end{array}$ & $\begin{array}{l}21(52,5 \%) \\
19(47,5 \%)\end{array}$ \\
\hline $\begin{array}{cl}\text { Jenis } & \text { Analgetik: } \\
& \text { Morfin } \\
\text { - } & \text { Fentanyl } \\
\end{array}$ & $\begin{array}{l}10(50 \%) \\
10(50 \%)\end{array}$ & $\begin{array}{r}13(65 \%) \\
7(35 \%) \\
\end{array}$ & $\begin{array}{l}23(57,5 \%) \\
17(42,5 \%)\end{array}$ \\
\hline Total & $20(100 \%)$ & $20(100 \%)$ & $40(100 \%)$ \\
\hline
\end{tabular}

Dari tabel 2 diketahui berdasarkan karakteristik jenis kelamin mayoritas responden lakilaki $21(52,5 \%)$ responden, lebih dari separuh jumlah responden merupakan pasien post craniotomy $21(52,5 \%)$ responden, dan sebagian besar responden menggunakan analgetik morfin $23(57,5 \%)$ responden.

\section{Pengaruh intensitas nyeri sebelum dan setelah dilakukan kompres hangat dan akupresur pada masing-masing kelompok}

Tabel 3

Distribusi Frekuensi Responden Penelitian berdasarkan Skala Nyeri pada Kelompok Intervensi Kompres Hangat dan Kelompok Intervensi Akupresur di Ruang ICU Rumah Sakit Margono Soekarjo pada Januari-Maret $2018(\mathrm{n}=40)$

\begin{tabular}{lccc}
\hline \multicolumn{1}{c}{ Skala Nyeri } & $\begin{array}{c}\text { Kompres Hangat } \\
\mathbf{f}(\boldsymbol{\%})\end{array}$ & $\begin{array}{c}\text { Akupresur } \\
\mathbf{f}(\boldsymbol{\%})\end{array}$ & Total \\
\hline Skala Nyeri Post Intubasi Sebelum Intervensi: & & & \\
- Nyeri ringan & $1(5 \%)$ & $1(5 \%)$ & $2(5 \%)$ \\
- Nyeri sedang & $12(60 \%)$ & $13(65 \%)$ & $25(62,5 \%)$ \\
- Nyeri berat & $7(35 \%)$ & $6(30 \%)$ & $13(32,5 \%)$ \\
\hline Skala Nyeri Post Intubasi Setelah Intervensi: & & & \\
- Nyeri ringan & $5(25 \%)$ & $4(20 \%)$ & $9(22,5 \%)$ \\
- Nyeri sedang & $14(70 \%)$ & $13(65 \%)$ & $27(67,5 \%)$ \\
- Nyeri berat & $1(5 \%)$ & $3(15 \%)$ & $4(10 \%)$ \\
\hline Total & $20(100 \%)$ & $20(100 \%)$ & $40(100 \%)$ \\
\hline
\end{tabular}

Pada tabel 3 menunjukkan mayoritas responden merasakan nyeri post intubasi sebelum intervensi mayoritas merasa nyeri skala sedang yakni $25(62,5 \%)$ responden, 13 (32,5\%) responden mengalami nyeri berat, dan lainnya $2(5 \%)$ responden merasakan nyeri ringan. Mubarok, A., Hidayat, A., \& Febriyanto, S. / Efektivitas Akupressure Titik Hegu-Sangciu...Hal 52 dari 57 
Sedangkan, skala nyeri post intubasi setelah intervensi mayoritas merasa nyeri skala sedang yakni $27(67,5 \%)$ responden, $9(22,5 \%)$ responden mengalami nyeri ringan, dan lainnya $4(10 \%)$ responden merasakan nyeri berat.

Tabel 4

Pengaruh Intensitas Nyeri Sebelum dan Setelah Dilakukan Kompres Hangat pada Kelompok Intervensi dan Kelompok Kontrol di Ruang ICU Rumah Sakit Margono Soekarjo Purwokerto

\begin{tabular}{lccccc}
\hline \multirow{2}{*}{ Kelompok Intervensi } & \multicolumn{2}{c}{ Pre } & \multicolumn{2}{c}{ Post } & \multirow{2}{*}{$\boldsymbol{p}$} \\
\cline { 2 - 5 } & Mean & SD & Mean & SD & $\mathbf{0 . 0 0 0}$ \\
Kompres Hangat & 6.05 & 1.191 & 4.35 & 1.226 & $\mathbf{0 . 0 7 4}$ \\
Akupresur & 5.65 & 1.182 & 4.80 & 1.473 & \\
\hline
\end{tabular}

Berdasarkan tabel 4 diketahui nilai p pada kelompok kompres hangat adalah 0.000 $(\mathrm{p}<0.05)$ hal ini menunjukkan bahwa ada pengaruh intensitas nyeri yang bermakna sebelum dan sesudah dilakukan kompres hangat. Pada kelompok akupresur diperoleh nilai p 0.074 (p>0.05) yang menunjukkan bahwa tidak ada pengaruh intensitas nyeri yang bermakna antara pengambilan data pretest dan postest pada kelompok akupresur.

\section{Pembahasan}

Berdasarkan data penelitian diketahui berdasar karakteristik jenis kelamin mayoritas responden laki-laki $21(52,5 \%)$ responden. Mayoritas responden merupakan pasien post craniotomy $21(52,5 \%)$ responden. Sebagian responden menggunakan analgetik morfin 23 $(57,5 \%)$ responden. Mayoritas responden merasakan nyeri sedang setelah tindakan operasinya 25 $(62,5 \%)$ responden, $13(32,5 \%)$ responden mengalami nyeri berat, dan lainnya $2(5 \%)$ responden merasakan nyeri ringan. Untuk selanjutnya pada penelitian tidak dianalisa lebih lanjut pengaruh kedua karakteristik terhadap intensitas nyeri.

Analisis pengaruh intensitas nyeri sebelum dan setelah dilakukan kompres hangat dan akupresur pada masing-masing kelompok didapatkan nilai $\mathrm{p}$ pada kelompok kompres hangat adalah $0.000(\mathrm{p}<0.05)$ yang menunjukkan bahwa ada pengaruh intensitas nyeri yang bermakna sebelum dan sesudah dilakukan kompres hangat. Pada kelompok akupresur diperoleh nilai $\mathrm{p}=$ 0.074 ( $\mathrm{p}>0.05$ ) yang menunjukkan bahwa tidak ada pengaruh intensitas nyeri yang bermakna antara pengambilan data pretest dan postest pada kelompok akupresur. 
Hal ini sesuai dengan hasil penelitian yang dilakukan oleh Aini (2010) bahwa penggunaan kompres hangat untuk area yang tegang dan nyeri terbukti meredakan nyeri dengan cara mengurangi spasme otot yang disebabkan oleh iskemia, yang merangsang nyeri dan menyebabkan vasodilatasi dan peningkatan aliran darah ke area tersebut. Sejalan juga dengan pendapat Smeltzer \& Bare (2001), kompres hangat mempunyai keuntungan meningkatkan aliran darah ke suatu area dan kemungkinan dapat turut menurunkan nyeri dengan mempercepat penyembuhan.

Kompres hangat bermanfaat untuk meningkatkan suhu kulit lokal, melancarkan sirkulasi dan menstimulasi pembuluh darah, mengurangi spasme otot dan meningkatkan ambang nyeri, menghilangkan sensasi nyeri, merangsang peristaltik usus, pengeluaran getah radang, serta memberikan ketenangan dan kenyamanan (Simkin, 2005).

Akupresur merupakan tindakan suportif dengan mekanisme pijat yang dapat menurunkan nyeri (Adiguna, 2014). Tindakan akupresur merupakan upaya mengaktifkan thalamus mengeluarkan hormon endorpin enkafalin yang dapat mengatasi nyeri dan eksitasi psikogenik sistem analgesia sentral secara stimultan menurunkan rasa nyeri (Abbaspoor et al, 2013). Namun dalam penelitian ini tidak terbukti dapat menurunkan nyeri post intubasi.

\section{KESIMPULAN}

Dari hasil penelitian menunjukan kompres hangat lebih efektif digunakan dalam mengatasi nyeri pasien post intubasi. Hasil penelitian diharapkan dapat dijadikan sumber informasi dan dasar pengetahuan bagi dunia keperawatan guna mengembangkan pengetahuan tentang manfaat terapi komplementer dalam mengatasi nyeri post intubasi. 


\section{DAFTAR PUSTAKA}

Adiguna, P. (2014). Titik-titik ajaib penumpas penyakit. Yogyakarta : Genius Publisher.

Anderson, O. (2007). Heat treatment. Diakses pada tanggal 2 Maret 2018 dari http:/www.warmbuddy.com.

Aini, S. (2010). Pengaruh kompres hangat terhadap perubahan tingkat nyeri pasien rematik di Kelurahan Koto Panjang Ikur Koto Kecamatan Koto Tangah Padang Tahun 2010. Padang: Universitas Andalas.

Arikunto, S. (2010). Prosedur penelitian suatu pendekatan praktik. Jakarta : Rineka Cipta.

Asmadi. (2008). Teknik prosedural keperawatan : konsep dan aplikasi kebutuhan dasar klien. Jakarta : Salemba Medika.

Dahlan, M.S. (2011). Statistik untuk kedokteran dan kesehatan. Jakarta : Salemba Medika.

Demir, Y. (2012). Non-pharmacological therapies in pain management. Turkey: Abant İzzet Baysal University, Bolu Health Sciences High School.

Efendi, Ferry, \& Makhfudli. (2009). Keperawatan kesehatan komunitas : teori dan praktik dalam keperawatan. Jakarta : Salemba Medika.

Gloth, F. M. et al. (2001). The functional pain scale: reliability, validity and responsiveness in an elderly population. Journal of the American Medical Directors Association, 2(3), 110-114.

Hidayat, A. (2013). Pengantar kebutuhan dasar manusia-aplikasi konsep dan proses keperawatan. Jakarta : Salemba Medika.

Mubarok, A., Hidayat, A., \& Febriyanto, S. / Efektivitas Akupressure Titik Hegu-Sangciu...Hal 55 dari 57 
Jurnal IImu Keperawatan Medial Bedah 1 (2), Desember 2018, 1-57

ISSN 2338-2058 (print), ISSN 2621-2986 (online)

Mahmud, M. H. (2007). Terapi air. Jakarta : Qultum Media.

Malde AD, Sarode V. (2007). Attenuation of the Hemodynamic Response to Endotracheal Intubation: Fentanil versus Lignocaine. The Internet $J$ of Anesth.

Masjoer, Arif, dkk. (2001). Kapita selekta kedokteran. Edisi Ketiga. Jilid 1. Jakarta : Media Aesculapius.

Mcmanuc, J.G., \& Harrison, B. (2005). Pathophysiology of acute pain: in pain and sedation management in the 21 st century. Departement Emerg Medclin.

Morgan, E., et al. (2006). Airway management. In: Clinical Anesthesiology. 4th ed. New York: A Lange medical book.

Morgan, G.E. et al. (2002). Nonvolatile anesthetic agents. In:Lange Clinical Anesthesiology. 3rd ed.New York:Mc Graw-Hill;p 169-72.

Mort, T.C. (2007). Complication of emergency tracheal intubation: hemodynamic alterations part I. J Intensive Care Med. Sage Publication 22;157.

Nicholson, L. \& O'Brien, M. (2007). Intensive care high dependancy orientation learning package. Assessing The Adequacy of Ventilation and Oxygenation.

Oka, Putu Sukanta. (2008). Pijat akupresur untuk kesehatan. Jakarta: Penebar Plus.

Park, S.Y. Et al. (2011). Application of triamcinolone acetonide paste to the endotracheal tube reduces postoperative sore throat: a randomized controlled trial.Can J Anaesth.

Prasetyo, S.N. (2010). Konsep dan proses keperawatan nyeri. Jakarta: Graha Ilmu.

Sally, R. (2013). Perbandingan kejadian nyeri tenggorokan paska ekstubasi akibat penggunaan pipa endotrakea. Yogyakarta : Universitas Gadjah Mada.

Smeltzer, S.C., \& Bare, B.G. (2001). Buku ajar keperawatan medikal-bedah Brunner \& Suddarth. Edisi 8. Volume 1. Jakarta : EGC.

Samsudin. (2013). Pengaruh terapi pijat refleksi terhadap penurunan tekanan darah pada penderita hipertensi di Desa Leyangan Kecamatan Ungaran Timur Kabupaten Semarang. Skripsi. Semarang : Sekolah Tinggi Ilmu Kesehatan Ngudi Waluyo.

Tambayong, J. (2000). Patofisiologi untuk keperawatan. Jakarta : EGC.

Tamsuri, A. (2007). Konsep dan penatalaksanaan nyeri. Jakarta: EGC.

Thompson, L. (2006). Evidence based practice tracheal suctioning of adults with an artificial airway. Thompson \& Gale. 2006. Intensive Care Unit.

Wardani, D.S. (2011). Perilaku nyeri pasien post operasi di Rumah Sakit Umum Pusat H. Adam Malik Medan. Medan: Universitas Sumatera Utara.

Mubarok, A., Hidayat, A., \& Febriyanto, S. / Efektivitas Akupressure Titik Hegu-Sangciu...Hal 56 dari 57 
Jurnal IImu Keperawatan Medial Bedah 1 (2), Desember 2018, 1-57

ISSN 2338-2058 (print), ISSN 2621-2986 (online)

Wasis. (2008). Pedoman riset praktis untuk profesi perawat. Jakarta : EGC.

Widyaningrum, H. (2013). Pijat refleksi dan 6 terapi alternatif lainnya. Yogyakarta : Media Pressindo.

Mubarok, A., Hidayat, A., \& Febriyanto, S. / Efektivitas Akupressure Titik Hegu-Sangciu...Hal 57 dari 57 